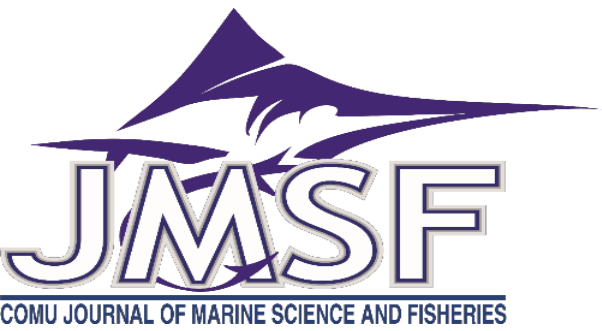

\title{
Recent Occurrence of Shortfin Mako Shark, Isurus oxyrinchus Rafinesque, 1810 (Chondrichthyes: Lamnidae), from the North-Eastern Mediterranean Coast of Turkey
}

\author{
Deniz Ergüden ${ }^{1 *}$, Deniz Ayas $^{2}$, Hakan Kabasakal ${ }^{3}$ \\ ${ }^{1}$ İskenderun Technical University, Marine Sciences and Technology Faculty, Marine Sciences Department, 31220, İskenderun, Hatay, \\ Turkey \\ ${ }^{2}$ Faculty of Fisheries, Mersin University Yenişehir Campus, 33160, Mersin, Turkey \\ ${ }^{3}$ Ichthyological Research Society, Tantavi Mahallesi, Menteşoğlu Caddesi, İdil Apt., No:30, D: 4, 34764 Ümraniye, İstanbul, Turkey \\ Correspondent: deniz.erguden@iste.edu.tr; derguden@gmail.com \\ Received: 12.12.2020 Accepted: 02.03.2021 \\ Deniz Ergüden: Orcid 0000-0002-2597-2151 \\ Deniz Ayas: Orcid 0000-0001-6762-6284 \\ Hakan Kabasakal: Orcid 0000-0001-8189-9748
}

How to cite this article: Ergüden, D., Ayas, D. \& Kabasakal, H., (2021). Recent occurrence of Shortfin Mako Shark, Isurus oxyrinchus Rafinesque, 1810 (Chondrichthyes: Lamnidae), from the north-eastern Mediterranean coast of Turkey. COMU J. Mar. Sci. Fish, 4(1): 7985. DOI: 10.46384 jimsf.839454

Abstract: A young individual of Isurus oxyrinchus was caught by a commercial longline off Dana Island (Mersin Bay, northeastern Mediterranean Sea) at a depth of $72 \mathrm{~m}$ on May 18 2020 . Morphometric measurements of the specimen were recorded and its photographs were taken. The examined specimen is now being preserved in the Museum of Systematics at Faculty of Fisheries of Mersin University, under the reference number MEUFC-20-11-132. This occurrence of a young female specimen reported in this study is adding a new location (Mersin Bay) from the Mediterranean's Turkish waters.

Keywords: Isurus oxyrinchus, Lamnidae, Mersin Coast, Dana Island, Turkey

\section{Türkiye'nin Kuzeydoğu Akdeniz Kıyılarından Kısa Yüzgeçli Köpek Balığı Mako, Isurus oxyrinchus Rafinesque, 1810 (Chondrichthyes: Lamnidae)'un Son Bulunurluğu}

Özet: Isurus oxyrinchus'un genç bir bireyi, 18 Mayıs 2020 tarihinde Dana Adası açıklarında (Mersin Körfezi, Kuzeydoğu Akdeniz) 72 m derinlikte ticari balıkçılık sırasında pareketa ile yakalanmıştır. Örneğin morfometrik ölçümleri kaydedildi ve fotoğrafları çekildi. İncelenen örnek şu anda Mersin Üniversitesi Su Ürünleri Fakültesi Sistematik Müzesi'nde MEUFC-20-11-132 örnek numarasıyla muhafaza edilmektedir. I. oxyrinchus'un Doğu Akdeniz ve Türkiye sularında nadir görüldüğü aşikardır. Bu çalışmada bildirilen genç bir dişi bireyin bu bölgedeki varlığg Türkiye'nin Akdeniz sularına yeni bir lokalite (Mersin Körfezi) eklemektir.

Anahtar Kelimeler: Isurus oxyrinchus, Lamnidae, Mersin Sahili, Dana Adası, Türkiye

\section{Introduction}

The shortfin mako shark, Isurus oxyrinchus Rafinesque, 1810, is a member of the Lamnidae family. The shortfin mako is a solitary and cosmopolitan species (Last \& Stevens, 1994), and it is distributed worldwide in temperate and tropical waters (Ebert, Fowler, \& Compagno, 2013). In the eastern Atlantic, it is known from Norway to South Africa, including the Mediterranean (Compagno et al., 1989). It is also known from the western Atlantic, the Pacific, and the Indian Oceans (Compagno, 1984).

The shortfin mako shark has occasionally been recorded from all Turkish waters (Geldiay, 1969; 
Bilecenoglu, Taskavak, Mater, \& Kaya, 2002; Akyol \& Ceyhan, 2012; Akyol, Aydın, \& Kara, 2013; Kabasakal, 2015; Kabasakal \& Bilecenoglu, 2020) except the Black Sea (Bilecenoglu, Kaya, Cihangir, \& Çiçek, 2014). Historically, 70 years ago, existence of shortfin mako was documented from the Aegean Sea (off Marmaris) by Kabasakal \& De Maddelena (2011). This species was reported from Urla Bay (İzmir), in the Aegean Sea (Akyol et al., 2010, 2011). A few juvenile specimens were recorded from Iskenderun Bay (Eastern Mediterranean) (Erguden, Gurlek, \& Turan, 2013) and Saros Bay (Kabasakal \& Kabasakal, 2013). More recently, this species was reported from Edremit Bay, Northern Aegean Sea coast of Turkey (Tuncer \& Kabasakal, 2016) and also from Izmir Bay, Gokova Bay, and Fethiye Bay (Central and South Aegean Sea, Turkey) (Bengil, Akalın, Tüney Kızılkaya, \& Bengil, 2019).

Recent investigations in the Mediterranean suggest that the western (Bengil, Akalın, Tüney Kızılkaya, \& Bengil, 2019) and eastern basin
(Erguden et al., 2013 and Kabasakal, 2015) is a potential nursery area where bycatch of shortfin mako shark from the tuna and swordfish fishery consists almost exclusively of juvenile individuals (Ceyhan \& Akyol, 2014; IUCN, 2020).

The present study aims to provide new data on the distribution of $I$. oxyrinchus in the northeastern Mediterranean Sea, based on a record of a specimen caught off Dana Island (Mersin Bay).

\section{Material and Methods}

On May 18th, 2020, a female specimen of $I$. oxyrinchus $(100 \mathrm{~cm}, \mathrm{TL})$ was caught by a longline off Dana Island in Mersin Bay, (36 09' 419' ' N, 33 48' 040" E) from $72 \mathrm{~m}$ depth (Figure 1). All measurements and diagnostic characteristics and color were in agreement with literature (Compagno 1984; Compagno 2001. The specimen was preserved in the Museum of the Systematics, Faculty of Fisheries, Mersin University (No: MEUFC-20-11132), (Figure 2A, B).

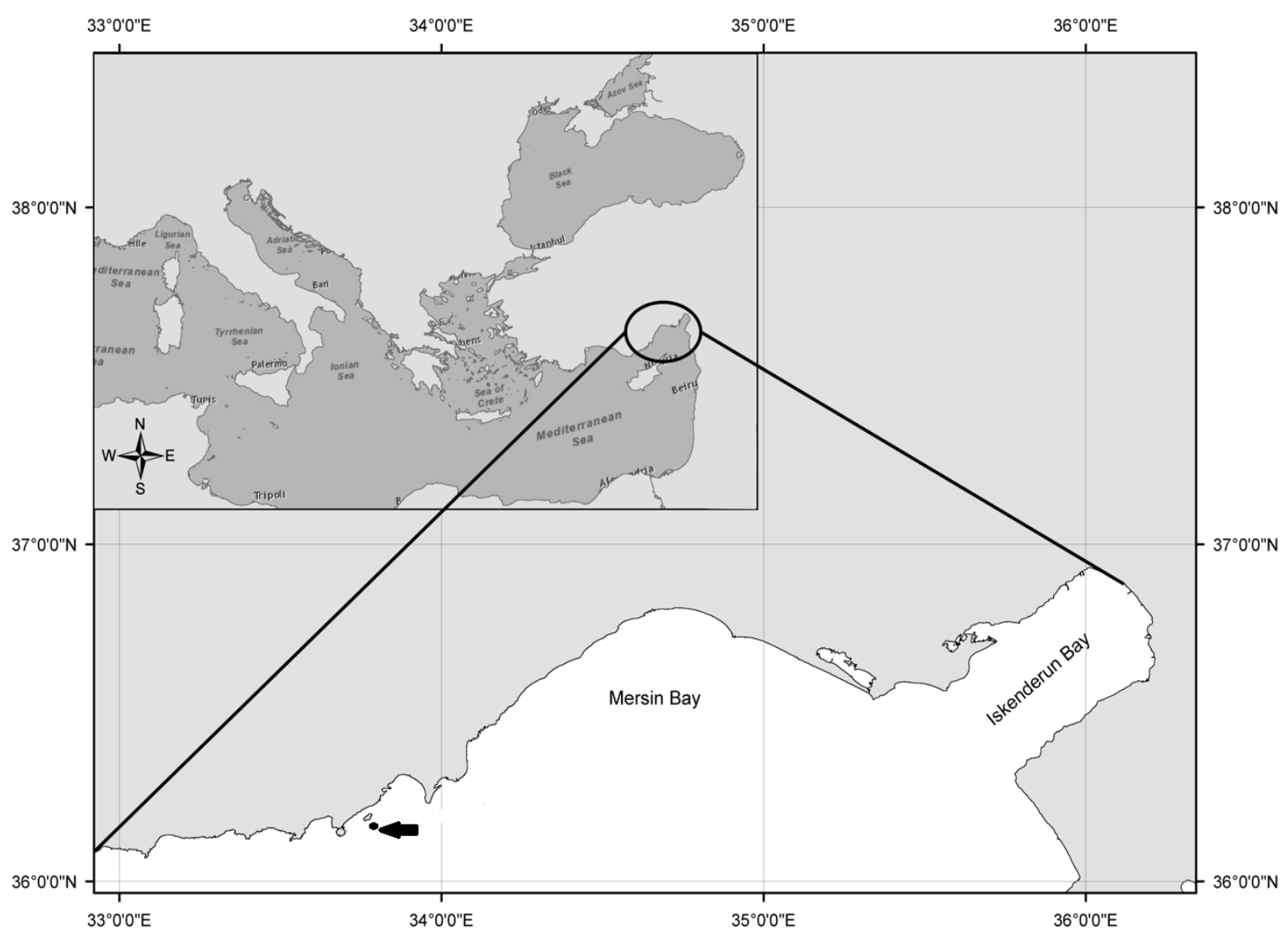

Figure 1. The capture locality (•) of Isurus oxyrinchus in the Mersin Bay (NE, Mediterranean) 

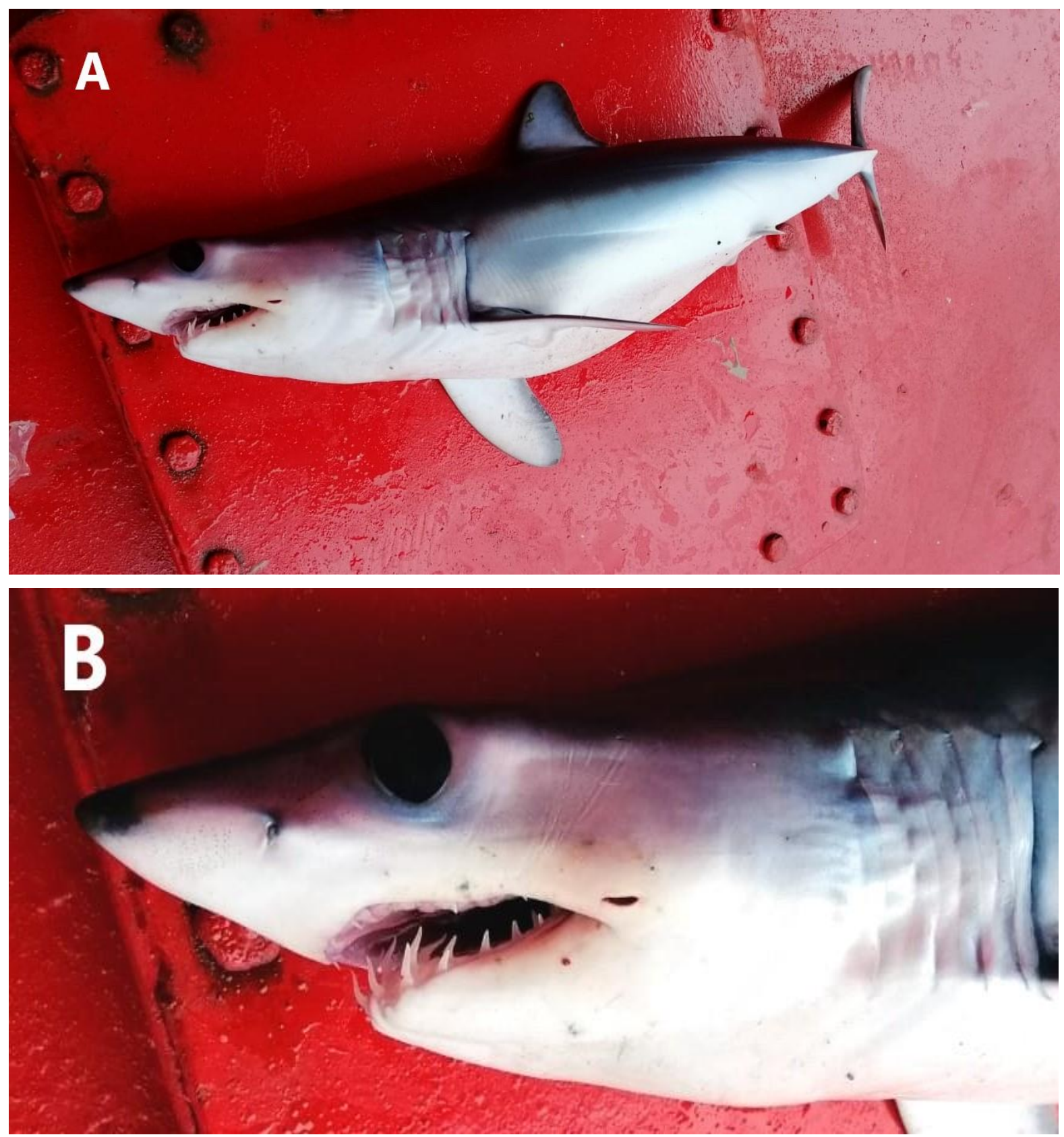

Figure 2. (A) Isurus oxyrinchus, $100 \mathrm{~cm}$ TL, young female, from Mersin Bay, Turkey; (B) ventral view of mouth and teeth

\section{Results}

The examined specimen's main characteristics are as follows: the body relatively slender; the snout is distinctly conical with large dark eyes. The teeth are long and blade-like without serrations or basal cusps. The foremost teeth of the lower jaw are visible even when the mouth is closed. The second dorsal fin and anal fin are extremely small. The pectoral fins are considerably shorter than the head. The tail is crescent-shaped with almost equal upper and lower lobes. A distinct caudal keel is present.

The coloration of the dorsal surface varies from grey to vivid blue. The ventral surface is paler to white. The morphometric measurements of $I$. oxyrinchus are summarized in Table 1 . The specimen was $100 \mathrm{~cm}$ in length (TL) and female. Previous records of $I$. oxyrinchus together with data on length, weight, catch date, fishing method and catch localities in the Aegean Sea and the Mediterranean Sea, Turkey are given in Table 2. 
Table 1. Morphometric measurements of Isurus oxyrinchus captured in Mersin Bay of Turkey

\begin{tabular}{ll}
\hline Measurements & cm \\
\hline Total length (TL) & 100.0 \\
Standard length (SL) & 83.5 \\
Mouth length & 8.0 \\
Eye length & 2.3 \\
Eye height & 2.2 \\
Pre-branchial length & 34.1 \\
Pre-orbital length & 12.3 \\
Pre-dorsal fin 1 length (D1) & 39.6 \\
Pre-dorsal fin 2 length (D2) & 72.5 \\
Pre-pectoral fin length & 44.3 \\
Pre-anal fin length & 70.2 \\
Pre-caudal fin length & 81.4 \\
\hline
\end{tabular}

\section{Discussion}

The shortfin mako shark is pelagic oceanic species but sometimes can inhabit areas close to shore. It usually lives between $1-500 \mathrm{~m}$ in depth (Quero, 1986; Golani, Ozturk, \& Basusta, 2006; Froese \& Pauly, 2020). This species has a low biological productivity with a triennial reproductive cycle and late age at maturity. The total length (TL) of I. oxyrinchus is commonly around $200-270 \mathrm{~cm}$ and the reported maximum total length is $445 \mathrm{~cm}$ and weight is $505.8 \mathrm{~kg}$ (Cervigon et al., 1992; Weigmann, 2016; Froese \& Pauly; 2020). However, Kabasakal \& De Maddelena (2011) reported a very large specimen, which was caught off Marmaris in the late 1950s, with an estimated TL of $585 \mathrm{~cm}$. The specimen was claimed to be the most massive shortfin mako shark ever recorded worldwide.

The young specimens are usually reported between $68-70 \mathrm{~cm}$ in length. Both male and female shortfin mako sharks reach sexual maturity at the age of 4-6 years. Adults are epipelagic in oceanic or coastal waters. They feed on bony fishes (mackerels, tunas, bonitos, anchovies, herrings, grunts, lancet fishes, cod, ling, whiting, Australian Salmon, yellowtails, sea basses, porgies, and swordfish), other sharks, cephalopods, turtles, billfish, and small cetaceans (Compagno, Ebert \& Smale, 1989; Last \& Stevens, 1994).

The shortfin mako shark is reputed for its speed and power in chasing prey. This species is potentially dangerous to humans and can attack swimmers and boats (Compagno, 2001). However, the shortfin mako shark is an essential target species for its flesh, fins and liver oil. According to De Maddalena \& Baensch (2005), the shortfin mako shark is present in the entire Mediterranean. This species is usually caught as bycatch in fisheries using longlines and driftnets that target tuna and swordfish (Megalofonou et al., 2005; Cailliet et al., 2009). Besides, it is also captured in gillnets, trammel nets, and sometimes trawls, particularly in coastal areas with narrow continental shelves (Camhi, Pikitch, \& Babcock, 2008; Martínez-Ortiz, Aires-da-Silva, Lennert-Cody, $\&$ Maunder, 2015). According to IUCN (2020), the North and South Atlantic and Mediterraenan populations of shortfin mako is in decline. However, the south Pacific population appears to be increasing but with fluctuating catch rates. The weighted global population trend estimated a median decline of $46.6 \%$, with the highest probability of $50-79 \%$ reduction for 72-75 years. Cavanagh \& Gibson (2007) classified the shortfin mako as "Critically Endangered" in the Mediterranean. The shortfin mako shark is considered as Endangered (EN) in the Global Red List Categories and Criteria, (Rigby et al., 2019). and it is listed on Annex I of UNCLOS, Annex I of the CMS Migratory Shark Memorandum of Understanding and Appendix II: Migratory species conserved through agreements of CMS (CMS, 2015). 
Table 2. Previous records of Isurus oxyrinchus from Turkish waters

\begin{tabular}{|c|c|c|c|c|c|c|}
\hline Location & Gear & $\begin{array}{l}\text { Length } \\
(\mathrm{cm})\end{array}$ & $\begin{array}{l}\text { Weight } \\
\text { (kg) }\end{array}$ & $\begin{array}{l}\text { Depth } \\
\text { (m) }\end{array}$ & Date & Reference \\
\hline $\begin{array}{l}\text { off Marmaris, SE } \\
\text { Aegean Sea }\end{array}$ & Fishing net & 585.0 우 & - & - & $1950 \mathrm{~s}$ & $\begin{array}{l}\text { Kabasakal \& De } \\
\text { Maddelena (2011) }\end{array}$ \\
\hline Izmir coast & - & - & - & - & 1969 & Geldiay (1969) \\
\hline $\begin{array}{l}\text { Saros Bay, SE } \\
\text { Aegean Sea }\end{array}$ & $\begin{array}{l}\text { Hook and } \\
\text { Line }\end{array}$ & 123.6 ठ & 14 & - & March 2012 & $\begin{array}{l}\text { Kabasakal \& } \\
\text { Kabasakal (2013) }\end{array}$ \\
\hline $\begin{array}{l}\text { Iskenderun Bay } \\
\text { Eastern } \\
\text { Mediterranean Sea }\end{array}$ & Purse seine & 69.8 ఠ & 2.28 & 54 & 2010 & $\begin{array}{l}\text { Erguden et al. } \\
\text { (2013) }\end{array}$ \\
\hline $\begin{array}{l}\text { Fethiye, } \\
\text { Mediterranean Sea }\end{array}$ & - & $200 q$ & - & - & June 2000 & Kabasakal (2015) \\
\hline Gulf of Mersin & Longline & - $\quad q$ & - & - & 2000 & \\
\hline Gulf of Mersin & Drift net & $250 \curvearrowright$ & - & - & January 2011 & \\
\hline Iskenderun Bay & Purse seine & $380 q$ & - & - & 2012 & \\
\hline Gulf of Antalya & Handline & $100 \widehat{\jmath}$ & - & - & November 2013 & \\
\hline Gulf of Antalya & $\begin{array}{l}\text { Stationary } \\
\text { net }\end{array}$ & $120 q$ & - & - & April 2015 & \\
\hline Foça, Aegean Sea & $\begin{array}{l}\text { Stationary } \\
\text { net }\end{array}$ & 65.0 우 & 4 & - & May 2015 & \\
\hline $\begin{array}{l}\text { Edremit Bay, } \\
\text { Northern Aegean } \\
\text { Sea }\end{array}$ & Net set & $74.7 \AA$ & 2.75 & $20-25$ & April 2016 & $\begin{array}{l}\text { Tuncer \& Kabasakal } \\
\text { (2016) }\end{array}$ \\
\hline $\begin{array}{l}\text { Izmir Peninsula } \\
\text { Central Aegean Sea }\end{array}$ & Purse seine & 180.9 & - & - & $1990 \mathrm{~s}$ & Kabasakal (2017a) \\
\hline Kusadas1 coast & - & - & - & - & December 2016 & Kabasakal (2017b) \\
\hline $\begin{array}{l}\text { Antalya Bay, } \\
\text { Mediterranean Sea }\end{array}$ & $\begin{array}{l}\text { Pelagic } \\
\text { longline }\end{array}$ & - $\quad q 0 \hat{0}$ & - & - & $2000 s$ & \\
\hline $\begin{array}{l}\text { Izmir Bay (Kırdeniz, } \\
\text { Foça, Central } \\
\text { Aegean Sea) }\end{array}$ & Gillnet & $76.5 q$ & 2.75 & 4 & May 2015 & Bengil et al. (2019) \\
\hline $\begin{array}{l}\text { Gökova Bay } \\
\text { (Akyaka, South } \\
\text { Aegean Sea) }\end{array}$ & Longline & 94.3 ๙ & 5.98 & - & February 2016 & \\
\hline $\begin{array}{l}\text { Fethiye Bay, Aegean } \\
\text { Sea }\end{array}$ & - & - & - & - & May 2017 & \\
\hline $\begin{array}{l}\text { off Dana island, } \\
\text { Mersin Bay }\end{array}$ & Longline & 100.2 q & - & 72 & May 2020 & This study \\
\hline
\end{tabular}

Male: $\tilde{\sigma}$, Female: $q$

Although I. oxyrinchus has been reported in the western and central Mediterranean and the Aegean Sea, the shortfin mako shark is reported for only the third time off Turkey's northeastern Mediterranean shores. This species is not targeted by commercial fisheries, but they are caught incidentally as bycatch. Data revealed that the present specimen $(100 \mathrm{~cm}, \mathrm{TL})$ is a young female of $I$. oxyrinchus. This record is critical to identify and assess the status of possible nursery areas for endangered elasmobranches to help future conservation efforts and highlight the importance of shark conservation.

The occurrence of this young specimen of $I$. oxyrinchus in the Mersin Bay (northeastern Mediterranean) may suggest that this area is potentially a breeding or nursery ground. Thus, we propose that further studies are needed in this region to monitor this species in the northeastern Mediterranean. Monitoring studies should be 
considered as a high priority area for the conservation of this species in the region.

\section{Acknowledgments}

The authors want to thank Özkan KARKIN from the fish farm for generously sharing the information and images.

\section{Authors Contributions}

Ergüden D.E: Designed the study, Data curation, Validation, Investigation, Formal analysis, Writing original draft, final editing. Ayas D: Validation, Supervision, Investigation, original draft, review \& editing. Kabasakal H: Data curation, Validation, Supervision, Investigation, Formal analysis, Writing original draft, Writing - review \& editing.

\section{Conflict of Interest}

The authors declare that they have no conflict of interest.

\section{References}

Akyol, O., Ceyhan, T., Erdem, M., \& Filiz, H. (2010). Investigations on the determination of swordfish (Xiphias gladius L.) fishing, mortality and by-catch ratios in the Aegean Sea. TUBITAK Project (No. 108O210) Final Report pp. 142 [in Turkish].

Akyol, O., Coker T., \& Percin, F. (2011). The very rare and little known fishes along the coast of Izmir (Aegean Sea, Turkey) in the past 40 years (1969-2008). Journal of Applied Ichthyology, 27, 1337-1345. doi:10.1111/j.1439-426.2011.01768.x

Akyol, O., \& Ceyhan, T. (2012). Turkish driftnet fishery for Albacore, Thunnus alalunga (Actinopterygii: Perciformes: Scombridae), and incidental catches in the Eastern Mediterranean. Acta Ichthyologica et Piscatoria, 42(2), 131-135. doi: 10.3750/AIP2011.42.2.06

Akyol, O., Aydın, I., Gülşahin, A., \& Kara, A. (2013). Records of three uncommon fishes from Izmir Bay (Aegean Sea, Turkey). Journal of Applied Ichthyology, 29, 925-926. doi: 10.1111/jai.12173

Bengil, E. G. T., Akalın, M., Tüney Kızılkaya, İ., \& Bengil, F. (2019). Biology of shortfin mako shark (Isurus oxyrinchus Rafinesque, 1810) from the Eastern Mediterranean Acta Aquatica Turcica, 15(4), 425-432. doi: 10.22392/actaquatr.545997

Bilecenoglu, M., Taskavak, E., Mater, S., \& Kaya, M. (2002). Checklist of the marine fishes of Turkey. Magnolia Press, Zootaxa, 113, 1-194. doi: 10.11646/zootaxa.113.1.1

Bilecenoglu, M., Kaya, M., Cihangir, B., \& Çiçek, E. (2014). An updated checklist of the marine fishes of Turkey. Turkish Journal of Zoology, 38(6), 901-929. doi: 10.3906/zoo-1405-60

Cailliet, G. M., Cavanagh, R. D., Kulka, D. W., Stevens, J. D., Soldo, A., Clo, S., Macias, D., Baum, J., Kohin, S., Duarte, A., Holtzhausen, J. A., Acuña, E., Amorim, A., Domingo, A. (2009). Isurus oxyrinchus. In: IUCN 2012. IUCN Red List of Threatened Species. Version 2012.2. <www.iucnredlist.org>. Download on 23 April 2013.

Camhi, M.D., Pikitch, E.K., \& Babcock, E.A. (2008). Sharks of the Open Ocean: Biology, Fisheries and Conservation. John Wiley \& Sons.

Cavanagh, R.D., \& Gibson, C. (2007). Overview of the Conservation Status of Cartilaginous fishes (Chondrichthyans) in the Mediterranean Sea. (42 p.). Switzerland and Malaga, Spain: IUCN, Gland.

Cervigón, F., Cipriani, R., Fischer, W., Garibaldi, L., Hendrickx, M., Lemus, A.J., Márquez, R., Poutiers, J.M., Robaina, G., \& Rodriguez, B. (1992). Fichas FAO de Identificación de Especies Para los Fines de la Pesca. Guía de Campo de las Especies Comerciales Marinas y de Aquas Salobres de la Costa Septentrional de Sur América. FAO, Rome: Preparado con el Financiamento de la Comisión de Comunidades Europeas y de NORAD.

Ceyhan, T., \& Akyol, O. (2014). On the Turkish surface longline fishery targeting swordfish in the Eastern Mediterranean Sea. Turkish Journal of Fisheries and Aquatic Sciences, 14(3), 825-830. doi: 10.4194/1303-2712-v14_3_25

Convention on the Conservation of Migratory Species of Wild Animals (CMS), (2015). Appendices I and II of the Convention on the Conservation of Migratory Species of Wild Animals (CMS). Access date: 12 Ocober 2020, http://www.cms.int/en/species/

Compagno, L. J. V. (1984). FAO Species Catalogue. Vol. 4. Sharks of the World: An Annotated and Illustrated Catalogue of Shark Species Known to Date. Part 1 - Hexanchiformes to Lamniformes. 125(4/1), (249 p.). FAO Fish. Synopsis, Rome: FAO.

Compagno, L. J. V., Ebert D. A., \& Smale, M. J. (1989). Guide to the Sharks and Rays of Southern Africa. (158 p.). London: New Holland (Publ.) Ltd.

Compagno, L. J. V. (2001). Sharks of the World. An Annotated and Illustrated Catalogue of Shark Species Known to Date: Bullhead, Mackarel and Carpet Sharks (Heterodontiformes, Lamniformes and Orectolobiformes). No. 1, Vol. 2, (269 p.). FAO Species Catalogue for Fishery Purposes. Rome: FAO. 
De Maddalena, A., \& Baensch, H. (2005). Haie im Mittelmeer. (240 p.). Stuttgart, Germany: Franckh-Kosmos Verlags-Gmb H \& Company.

Ebert, D.A., Fowler, S., \& Compagno, L. (2013). Sharks of the World. A Fully Illustrated Guide. Plymouth, United Kingdom: Wild Nature Press.

Erguden, D., Gurlek, M., \& Turan, C. (2013). A young Isurus oxyrinchus Rafinesque, 1810 (Chondrichthyes: Lamnidae) individual captured from Iskenderun Bay, Turkey. Mediterranean Marine Science, 14, 463-480. doi: $10.12681 / \mathrm{mms} .676$

Froese, R., \& Pauly, D. (2020). Fishbase. World Wide Web Electronic Publication. [version 12/2019]. Access date: 05 October 2020, http://www.fishbase.org/

Geldiay, R. (1969). Important Fishes found in the Bay of Izmir and their possible invasions. No. 11, 8135 p.). İzmir, Turkey: E.U. Fen Fakultesi Monografiler Serisi [in Turkish].

Golani, D., Ozturk, B., \& Basusta, N. (2006). Fishes of the Eastern Mediterranean. (259 p.). Istanbul, Turkey: Turkish Marine Research Foundation (Publication No. 24).

IUCN, (2020). IUCN Red List of Threatened Species. [version 3/2020]. Access date: 10 December 2020, http://www.iucnredlist.org/

Kabasakal, H., \& De Maddalena, A. (2011). A huge shortfin mako shark Isurus oxyrinchus Rafinesque, 1810 (Chondrichthyes: Lamnidae) from the waters of Marmaris, Turkey. Annales Series Historia Naturalis, 21, 21-24.

Kabasakal, H., \& Kabasakal, Ö. (2013). First record of a shortfin mako shark, Isurus oxyrinchus Rafinesque, 1810 (Chondrichthyes: Lamnidae) from the Bay of Saroz (NE Aegean Sea). Annales Series Historia Naturalis, 23(1), 27-32.

Kabasakal, H. (2015). Occurrence of shortfin makoshark, Isurus oxyrinchus Rafinesque, 1810, off Turkey's coast. Marine Biodiversity Records, 8, e134. doi: 10.1017/S1755267215001104

Kabasakal, H. (2017a). On the jaws of a shortfin mako shark, Isurus oxyrinchus, caught off the Izmir peninsula (Central Aegean Sea, Turkey). Annales Series Historia Naturalis, 27(2), 151154. doi: 10.19233/ASHN.2017.18

Kabasakal, H. (2017b). Notes on historical and contemporary catches of Lamniform sharks in Turkish waters. Annales Series Historia
Naturalis, 27(1), 51-57. doi: 10.19233/ASHN.2017.07

Kabasakal, H., \& Bilecenoglu, M. (2020). Shark infested internet: an analysis of internet-based media reports on rare and large sharks of Turkey. FishTaxa, 16, 8-18.

Last, P. R., \& Stevens, J. D. (1994). Sharks and Rays of Australia. (513 p). Australia: CSIRO.

Martínez-Ortiz, J., Aires-da-Silva, A. M., LennertCody, C. E., \& Maunder, M. N. (2015). The Ecuadorian artisanal fishery for large pelagics: species composition and spatio-temporal dynamics. PloS One, 10(8), p.e0135136. doi: 10.1371/journal.pone.0135136

Megalofonou, P., Yannopoulos, C., Damalas, D., De Metrio, G., Deflorio, M., De La Serna, J. M., \& Macias, D. (2005). Incidental catch and estimated discards of pelagic sharks from the swordwish and tuna fisheries in the Mediterranean Sea. Fisheries Bulletin, 103, 620-634.

Quero, J. C. (1986). Lamnidae. In P J.P. Whitehead, M.L. Bauchot, J.C. Hureau, J. Nielsen, \& E. Tortonese (Eds.), Fishes of the North-eastern Atlantic and the Mediterranean, Vol. I, (pp. 8586): UNESCO, Paris.

Rigby, C. L., Barreto, R., Carlson, J., Fernando, D., Fordham, S., Francis, M. P., Jabado, R. W., Liu, K. M., Marshall, A., Pacoureau, N., Romanov, E., Sherley, R. B., \& Winker, H. (2019). Isurus oxyrinchus. The IUCN Red List of Threatened Species 2019: e.T39341A2903170. Access date: $10 \quad$ December 2020, https://dx.doi.org/10.2305/IUCN.UK.2019.1.RLT S.T39341A2903170.en/

Tuncer, S., Kabasakal, H. (2016). Capture of a juvenile shortfin mako shark, Isurus oxyrinchus Rafinesque, 1810 Chondrichthyes: Lamnidae) in the Bay of Edremit, Northern Aegean Sea Turkey). Annales Series Historia Naturalis, 26(1), 31-35.

Weigmann, S. (2016). Annotated checklist of the living sharks, batoids and chimaeras (Chondrichthyes) of the world, with a focus on biogeographical diversity. Journal of Fisheries Biology, 88(1), 1-201. doi: 10.1111/jfb.12874 